\title{
Carbon Financial Markets Underlying Climate Change Mitigation, Pricing and Challenges: Technical Analysis
}

\author{
http://doi.org/10.21272/fmir.5(1).5-17.2021
}

Adil El Amri, ORCID: $\underline{\text { https://orcid.org/0000-0003-1849-8727 }}$

Professor, Member of LERSEM Laboratory, National School of Business and Management (ENCG) El Jadida, Coordinator: Professional Bachelor's degree: Management \& Administration of Organizations, F.P.S.B., University of Chouaib Doukkali, El Jadida, Morocco

\section{Salah Oulfarsi}

Professor, Member of LERSEM Laboratory, National School of Business and Management (ENCG) El Jadida, University of Chouaib Doukkali, El Jadida, Morocco

\section{Rachid Boutti}

Professor, President of the Chair UNESCO Sustainable Development, Founder of LaRGe Laboratory, Director of the CREMA Indexed International Journal and Expert at the CNRS, National School of Business and Management, University of Ibn Zohr, Agadir, Morocco

\section{Abdelhak Sahib Eddine}

Professor, Member of LERSEM Laboratory, National School of Business and Management (ENCG) El Jadida, University of Chouaib Doukkali, El Jadida, Morocco

\section{Aziz Hmioui}

Professor, National School of Business and Management (ENCG) Fez, University of Sidi Mohammed Ben Abdellah, Fez, Morocco

\begin{abstract}
Climate Change (CC) is a major issue of our century. Controlling the constraints of Greenhouse Gas (GHG) emissions through transformation into opportunities, in an organization to increase industrial production, has become a necessity. The main reason for this adoption was the effectiveness of energy management and responsible linkages that are being developed to determine the issues and opportunities of carbon finance for organizations. Through analysis of the European Union Emissions Trading Scheme (EU ETS) and the Clean Development Mechanism (CDM), this article presents and determinate the variables that influence the performance of the strategies of EU ETS players via the EUA allowances. Our study focuses on price changes in the EUA, being the most liquid carbon asset. In this regard, we highlighted the daily spot price of the EUA to highlight the daily changes affecting this price, given the high volatility in this Carbon financial market. The treatments of the determinants of CO2 prices (EUA) can be used to analyze the evolving and expanding carbon financial markets sphere. It features stylized facts about carbon financial markets from an economics and management perspective, as well as covering key aspects of pricing strategies (institutional decisions, energy prices and extreme weather events), climate change mitigation. Aimed at those with technical analysis, the $\mathrm{CO} 2$ prices within the framework of the EU ETS depend on several determinants. This paper constitutes an introduction to emission trading and an overview of the regulations governing Carbon financial markets. First, we detail the price changes in the EUA and primary energy prices. Second, we introduce the main characteristics of emissions trading, be it in terms of spatial and temporal limits, Clean Dark Spread, Clean Spark Spread and Switch Price. Third, we provide a technical analysis of atmospheric variables, structural variations and the Sanitary COVID-19 crisis and their impacts in the price development of EU CO2 allowances and presnt after conclusion some implications for future.
\end{abstract}

Keywords: Technical analysis, European Union Emissions Trading Scheme, Sanitary COVID-19 crisis, Determinants of $\mathrm{CO} 2$ prices (EUA), Climate change mitigation

JEL Classification: G30, O16, Q01, Q51, Q54.

Cite as: El Amri, A., Oulfarsi, S., Boutti, R., Sahib Eddine, A., Hmioui, A. (2021). Carbon Financial Markets Underlying Climate Change Mitigation, Pricing and Challenges: Technical Analysis. Financial Markets, Institutions and Risks, 5(1), 5-17. http://doi.org/10.21272/fmir.5(1).5-17.2021

Received: 23 December 2020

Accepted: 20 January 2021

Published: 30 March 2021

Copyright: (C) 2021 by the authors. Licensee Sumy State University, Ukraine. This article is an open access article distributed under the terms and conditions of the Creative Commons Attribution (CC BY) license (https://creativecommons.org/licenses/by/4.0/)

\section{Introduction}

Management research generally aims to describe, understand, explain or predict phenomena related to organizations. At the same time, the world of organizations is a world of complexity where it is impossible for 
the researcher to represent in all their details most of the phenomena he or she may study. Consequently, a way must be found to represent them in a simplified manner. Modelling is a response to this need.

To qualify this statement, our objective in this research work is to evaluate, analyze and explain the impact of the explanatory variables (primary energy variables, atmospheric variables, fuel modification variables, structural movement variables [CO2 emissions information] and the Sanitary COVID-19 crisis variable) on the variable to be explained (EUA price variable), in order to detect and clear up the practices of the Responsible Management of companies of the European Union Emissions Trading Scheme (EU ETS). We can highlight these statements and variables in the figure opposite.

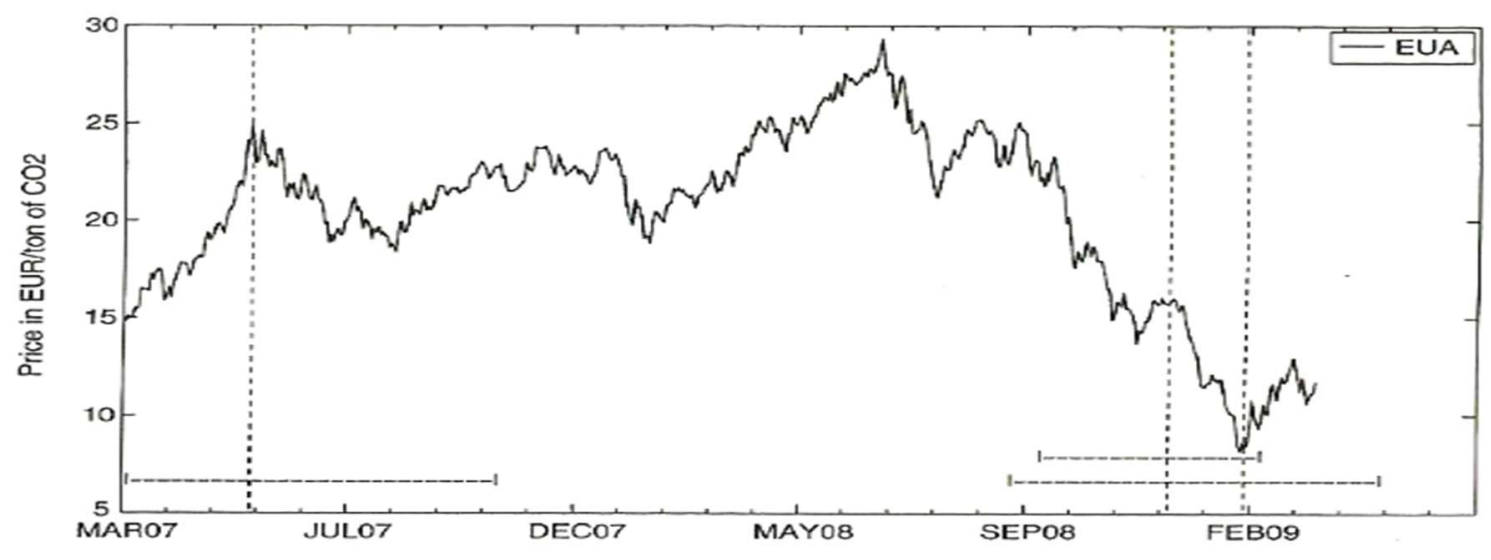

Figure 1. EUA with three movements (vertical lines) and 95\% confidence interval (horizontal lines)

Source: CHEVALLIER, Julien. Econometric Analysis of Carbon Markets: the European Union Emissions Trading Scheme and the Clean Development Mechanism. p.29.

With the intention of showing the impact of structural movements, particularly the Sanitary COVID-19 crisis in 2019, on the performance of the responsible strategies of European Union Emissions Trading Scheme (EU ETS) market players, three characteristics have been unveiled: (1) lower industrial production than in previous years, (2) lower EUA demand and (3) falling EUA prices (to address liquidity problems, players sold their EUA allocations).

\section{Literature Review}

Following the pioneering work by Christiansen and al. (2005), Chevallier (2012) produced the first literature reviews on the carbon price development in their respective publications. This work was further elaborated by Lebatt and White (2007).

Based on economic analysis (essentially demand and supply fundamentals), Christiansen et al. (2005) have identified the following factors as being the price determinants in the EU ETS: strategy and regulatory issues; market fundamentals, the role of fuel-switching, weather and production levels. Christiansen and al. (2005) and Alberola et al. (2008) were he first analyses to uncover econometrically the relations between energy markets and the $\mathrm{CO} 2$ price.

Based on Phase I spot and futures data, the former group of authors emphasizes that the nature of this relationship between energy and carbon prices varies depending on the period under consideration (Phase I, Phase II or Phase III), and the major influence of institutional events.

In addition, Bunn and Fezzi (2007) have studied the causalities between CO2 and electricity variables (such as Clean Dark and Clean Spark Spreads, and switch price) during the first phases of the EU ETS.

Lebatt and White (2007) underlines a primordial element in functioning of EU ETS, to know the incorporation of two of three mechanisms of suppleness of Kyoto, even in the first stage (2005-2007), before the second stage (2008-2010), particularly, the Negotiable Emissions Permits (PEN) and the Mechanisms of Clean Development (MDP).

Faced with this official report, these last two mechanisms are developed to support firms (or countries) to accomplish their discounts allocated by programs $\mathrm{CO} 2$, even if there is a space of clarity a lot of use of which is made of these mechanisms as percentage of the complete objective of discount of programs. 
Finally, it is worth highlighting the work by Boutti, El Amri and Rodhain (2019), whose drivers a structural model of allowance price under the assumption of the performance of the Carbon Finance Strategy for Sustainable Finance is based on the reaction of the fundamentals of quota prices of the European Union Emissions Trading Scheme (EU ETS).

The former of group of authors establishes to show econometrically using multiple regression that changes in the price of carbon (EUA) react to changes in primary energy prices (mainly natural gas). Last but not least, macroeconomic fundamentals of carbon prices respond to the impact of the COVID-19 crisis during the phase III: 2013-2019.

\section{Specification of model variables/concepts}

We will highlight, at this level, the explained variable and the explanatory variables in the framework of our econometric work in order to test our research hypothesis. Research hypothesis: The performance of the Carbon Finance strategy for Responsible Management is influenced by the Sanitary COVID-19 crisis during phase IIII of the EU ETS.

2.1. Specification of the variable to be explained: endogenous variable. This explained variable is measured by the change in EUA spot prices. It is used to express the return from the point of view of allocation on the carbon market: the European Union Emissions Trading Scheme (EU ETS).

2.1. Specification of explanatory variables: exogenous variables. Our objective is to highlight the link between the performance of the strategies of industrial players subject to the European Union Emissions Trading Scheme (EU ETS) for both periods via the variation of the EUA spot price and the primary energy variables, atmospheric variables, $\mathrm{CO} 2$ emissions information variables, fuel modification variables, structural movement variables and the Sanitary COVID-19 crisis variable COVID-19).

2.3. Variables for the third period EU ETS 2013 - 2019. The variables for the third period, known as the Kyoto Protocol commitment phase (KP) of the European Union Emissions Trading Scheme (EU ETS) are also presented in four groups (A - B - C and D) in the following table:

Table 1. Presentation of Explanatory Variables for the Third Period of the EU ETS

\begin{tabular}{|c|c|c|}
\hline \multicolumn{3}{|l|}{ Explanatory variables } \\
\hline \multicolumn{3}{|c|}{ Group A: Primary Energy Variables } \\
\hline Variations in the price of Brent & + & Var. 01 \\
\hline Variations in the price of gas & - & Var. 02 \\
\hline Coal Price Variations & - & Var. 03 \\
\hline \multicolumn{3}{|c|}{ Group B: Fuel Modification Variables in Power Generation } \\
\hline Clean Spark Spread & - & Var. 04 \\
\hline Clean Dark Spread & + & Var. 05 \\
\hline \multicolumn{3}{|c|}{ Group C: Structural Movement Variables } \\
\hline Dummy Sanitary crisis COVID-19 & + & Var. 07 \\
\hline $\begin{array}{l}\text { The impact of economic activity and the Sanitary COVID- } \\
19 \text { crisis on electricity production - SBF } 250 \text { variations }\end{array}$ & - & Var. 08 \\
\hline \multicolumn{3}{|c|}{$\begin{array}{ll} & \text { Group D: Atmospheric variables } \\
\end{array}$} \\
\hline Extremely Cold Dummy & + & Var. 09 \\
\hline Extremely Hot Dummy & + & Var. 10 \\
\hline Normal Seasonal Variations & + & Var. 11 \\
\hline
\end{tabular}

Source: Boutti and al. (2019).

According to the table above, for the third period of the EU ETS we have chosen ten variables as the first period. Nevertheless, we have replaced the variable Structural movement dummy with the Sanitary COVID19 crisis dummy. Thus six (06) explanatory variables have a positive expected sign and four (04) explanatory variables have a negative expected sign.

\section{Estimation of the econometric model EU ETS}

3.1. EU ETS model specification. Econometrically, to measure and study the contribution of primary energy variables, fuel modification variables of energy production, structural motion variables and atmospheric variables on the performance of EU ETS actors' strategies during Phase III (2013-2019). As a reminder, we have already studied these two phases as follows:

$>\quad$ from July 1, 2005 to April 6, 2007 (data from the Phase I test phase) ; 
from January 4, 2008 to April 30, 2010 (data from Phase III, known as the 1st commitment period of the Kyoto Protocol).

Our study aims to show the performance of the strategies of the EU ETS players via the EUA award. In order to achieve this, we can use a multiple linear model (multiple regression) as the theory formalizes it with the introduction of two categories of variables: the endogenous variable and several exogenous variables.

The general linear model is a generalization of the simple regression model in which several explanatory variables are included.

$Y_{t}=\beta_{0}+\beta_{1} X_{1 t}+\beta_{2} X_{2 t}+\ldots+\beta_{k} X_{k t}+\varepsilon_{t} \operatorname{pour} t=1, \ldots, n$

The parameter $\beta \mathrm{i}$ is called the partial regression coefficient, it measures the variation of $\mathrm{Y}$ when $\mathrm{Xi}$ increases by one unit and the other explanatory variables are kept constant. $\varepsilon$ represents the random error, it is unobservable and includes both the measurement errors on the observed values of $\mathrm{Y}$ and all other explanatory factors not taken into account in the model.

Multiple regression aims to explain a dependent variable $\mathrm{Y}$ and $\mathrm{p}$ explanatory variables $\mathrm{X} 1, \mathrm{X} 2, \mathrm{X} 3, \ldots, \mathrm{Xp}$ $(p>1)$. Then, if this relation is confirmed, evaluate its intensity.

To determine the variables that influence the performance of EU ETS actors' strategies via the EUA price, we adopted the formulation and model we want to estimate, as follows:

$$
\text { PERFEUA } A_{i, t}=\alpha W_{i, t}+\beta X_{i, t}+\chi Z_{i, t}+\delta Y_{i, t}+\varepsilon_{i, t}
$$

To get to the heart of the matter, the above table includes four groups of addressable action variables on the performance of the strategies of EU ETS actors via the EUA award.

Table 2. The four groups of variables in the econometric study of the EU ETS time series

\begin{tabular}{|l|c|c|}
\hline PER F EUA ${ }_{i, t}$ & $\begin{array}{c}\text { Performance of EU ETS actors' strategies } \\
\text { via the EUA price }\end{array}$ & $\begin{array}{c}\text { Groups } \\
\text { variables }\end{array}$ \\
\hline$W_{i, t}$ & Primary energy variables & Group A \\
\hline Brent $_{i, t}$ & Variations in the price of Brent & (Var. 02) \\
\hline Gas $_{i, t}$ & Changes in the price of gas & (Var. 03) \\
\hline Coal $_{i, t}$ & Coal price changes & Group B \\
\hline$X_{i, t}$ & Fuel modification variables of energy production & (Var. 04) \\
\hline $\mathrm{CSS}_{\mathrm{i}, \mathrm{t}}$ & Clean Spark Spread & Gar. 05) \\
\hline $\mathrm{CDS}_{\mathrm{i}, \mathrm{t}}$ & Clean Dark Spread & (Var. 06) \\
\hline$Z_{i, t}$ & Structural movement variables & (Var. 07) \\
\hline $\mathrm{DMS}_{\mathrm{i}, \mathrm{t}}$ & Structural Dummy Movement for Phase II & (Var. 08) \\
\hline $\mathrm{DCS}_{\mathrm{i}, \mathrm{t}}$ & Dummy Sanitary crisis COVID-19 for phase IIII & Group D \\
\hline $\mathrm{SBF}_{\mathrm{i}, \mathrm{t}}$ & electricity production - SBF 250 variations & (Var. 09) \\
\hline$Y_{i, t}$ & Atmospheric variables & (Var. 10) \\
\hline $\mathrm{DEF}_{\mathrm{i}, \mathrm{t}}$ & Extremely Cold Dummy & (Var. 11) \\
\hline $\mathrm{DEC}_{\mathrm{i}, \mathrm{t}}$ & Extremely Hot Dummy & Error Term \\
\hline $\mathrm{VNS}_{\mathrm{i}, \mathrm{t}}$ & Normal Seasonal Variations & \\
\hline$\varepsilon_{i, t}$ & Random variable (error term), following a normal law $N=\left(0, \delta^{2}\right)$ & \\
\hline
\end{tabular}

Source: Boutti and al. (2019).

First, group A of primary energy variables $\left(W_{i, t}\right)$ contains three addressable action variables, namely, changes in the price of Brent (Brent i,t) [Var. 01], changes in the price of gas (Gas i,t) [Var. 02], and changes in the price of coal (Coal i,t) [Var. 03]. 
Second, group B of the variables of modification of the fuel of energy production shows in force two addressable action variables; the Clean Spark Spread (CSS i,t) [Var. 04] and the Clean Dark Spread (CDS i,t) [Var. 05].

Thirdly, group C of structural movement variables involves three variables; the Structural Movement Dummy for phase II (DMS i,t) [Var. 06], the Sanitary COVID-19 crisis Dummy for phase III (DCS i,t) [Var. 07] and the impact of economic activity and the financial crisis on electricity production - SBF 250 Variations (SBF i,t) [Var. 08].

Finally, group D of atmospheric variables highlights Extremely Cold Dummy (DEF i,t) [Var. 09], Extremely Hot Dummy (DEC i,t) [Var. 10], and Normal Seasonal Variations (VNS i,t) [Var. 11].

3.2. Testing the stationarity of variables in the EU ETS model. To estimate the parameters of a model on data in time series form it is undoubtedly necessary to test the stationarity of the variables. Indeed, with nonstationary variables that contain a trend, for example, some regressions become spurious. This problem frequently arises when two non-stationary variables regress on each other and give rise to a statistically significant causal relationship.

Thus, although these results speak for themselves, they may only be the shadow of an association between variables not included in the model. As a result, one of the most elementary and preliminary tests for the use of time series estimation methods is the unit root test. It is a stationarity test based on the results of the regression of the variable to be tested on a constant, over time, and on its first shift. Generally, a stationary variable maintains a constant mean and variance over the period of its study. Thus, an ascending or descending trend materializes respectively a positive or negative trend. The latter being, for example, the result of a memory in the series whose current values are linked to those of the past.

On the other hand, a chronological series can be marred by a shock that it has suffered previously and whose repercussions are still persistent. Thus, if a trend or process is affected by a shock, unit root tests make it possible to detect it and correct it by first or third differences. If, on the other hand, this correction proves unsuccessful, one must be warned of the possibility of the existence of a process in the form of a moving average which is tested by regressing the series on its first or second order moving average. In some cases, one should not be surprised if the variable takes the form of a time series with a memory, a shock and a moving average. In this case, the correction takes the form of a first- or second-order differentiation with elimination of the moving average.

To carry out the stationarity test, we use the augmented Dicky-Fuller test. In fact, in addition to its robustness in the event of the existence of instability in the variance of the variable, it provides a significant warning of the existence of moving average processes (Greene, 2012).

\section{Results, discussions and critical issues}

The methodology to be adopted to achieve the objective of our work is to use a set of econometric methods and techniques. In order to do this, we will use tests under the Eviews software version 7.2.

4.1. Empirical tests used for the EU ETS model. L'objectif essentiel de ces différents tests c'est pour éviter des régressions fallacieuses entre différentes variables du modèle à estimer. Notre étude comporte trois tests ad-hoc.

The main objective of these different tests is to avoid spurious regressions between different variables of the model to be estimated. Our study includes three ad-hoc tests.

1) «Empirical test 1 » the correlation analysis: the multiple correlation coefficient, it measures the combined correlation of all the variables of the model. It gives the percentage of explanation of the variable to be explained by the explanatory variables. The adjusted R2 coefficient of determination is more appropriate for comparing regression models of a variable explained by different sub-groups of explanatory variables (« subgroups of explanatory variables $»)$;

2) « Empirical test 1 » analysis of variance: The analysis of variance is used to assess the quality of the fit. It is a global test on all the coefficients of the explanatory variables. This test calculates the ratio of the variance explained by the model to the residual variance. The regression corresponds to the variation of the "EUA spot price" which is explained by its relation with the other variables (primary energy variables, structural movement variables and atmospheric variables) and the residuals representing the variation of the 
other variables which cannot be explained by the "EUA spot price $»^{1}$. The hypotheses to be tested are as follows:

$>\quad \mathbf{H}_{0}: \beta_{1}=\beta_{2}=\ldots=\beta_{p}=0$;

$>\quad \mathbf{H}_{1}$ : at least one of the coefficients $\beta_{i}$ is different from zero.

3) « Empirical test 3 » standard deviation and Student's test: These analyses show the significance of the variables for our model mentioned above. If the probability is less than 0.05 (for a $95 \%$ confidence index), then the variable is significant. The non-significant variables can then be removed to find the most relevant model. The sign of the correlation coefficient is then examined. If the coefficient is positive, then a positive change in the independent variable leads to a positive change in the dependent variable (Boutti and al., 2019).

Our objective for Phase III of the European Union Emissions Trading Scheme (EU ETS) is to test the research hypothesis, namely:

Research Hypothesis: The performance of the Carbon Finance strategy for Responsible Management is influenced by the Sanitary COVID-19 crisis during Phase IIII of the EU ETS.

The analysis of this phase of the European Union Emissions Trading Scheme (EU ETS) has enabled us to compare our econometric results with the inventory of fixtures that we conducted previously. The data from phase IIII can be found in the Appendix of this thesis.

Table 3. Results of the stationarity tests of the variables of the Phase III EU ETS model

\begin{tabular}{|c|c|c|c|c|c|c|}
\hline & $\begin{array}{l}\text { No constant } \\
\text { term or trend }\end{array}$ & $\begin{array}{l}\text { With constant } \\
\text { term }\end{array}$ & With trend & $\begin{array}{l}\text { With constant } \\
\text { term and trend }\end{array}$ & $\begin{array}{l}\text { First } \\
\text { difference }\end{array}$ & Conclusion \\
\hline Brent & S & $\mathrm{S}$ & $\mathrm{S}$ & NS & NS & RVL \\
\hline CDS & $\mathrm{S}$ & $S$ & NS & NS & $\mathrm{S}$ & RVL \\
\hline Coal & $\mathrm{S}$ & $\mathrm{S}$ & $\mathrm{S}$ & $\mathrm{S}$ & $\mathrm{S}$ & RVL \\
\hline $\mathrm{CSS}$ & $\mathrm{S}$ & $\mathrm{S}$ & $\mathrm{S}$ & $\mathrm{S}$ & $\mathrm{S}$ & RVL \\
\hline DEC & $\mathrm{S}$ & $S$ & $\mathrm{~S}$ & $\mathrm{~S}$ & NS & RVL \\
\hline DEF & $\mathrm{S}$ & $\mathrm{S}$ & $\mathrm{S}$ & NS & $\mathrm{S}$ & RVL \\
\hline GAS & $\mathrm{S}$ & $\mathrm{S}$ & $\mathrm{S}$ & $\mathrm{S}$ & NS & RVL \\
\hline SBF & $\mathrm{S}$ & $\mathrm{S}$ & $\mathrm{S}$ & $\mathrm{S}$ & NS & RVL \\
\hline VNS & $\mathrm{S}$ & $\mathrm{S}$ & $\mathrm{S}$ & $\mathrm{S}$ & $\mathrm{S}$ & RVL \\
\hline
\end{tabular}

N.B: $S=$ Stationary $;$ NS $=$ Non-Stationary $;$ RVL $=$ Retain Variable in Level

Source: Boutti and al. (2019).

The same results obtained for the variables of the first EU ETS phase are repeated for those of this third EU ETS phase of multiple regression. Admittedly, all the variables emerge free of the unit root effect, which can be used in their level form in a multiple linear regression model. Tests of the hypotheses of ordinary least squares show that it is possible to use this estimator, so as we prefer it in the case of testing the hypotheses that underlie it because it is the best unbiased linear estimator.

The analysis of « $\mathrm{R}^{2}$ or R-squared » and « Adjusted $\mathrm{R}^{2}$ » or « Adjusted R-squared » coefficients are different according to the results of the EU ETS Phase IIII multiple regression. Indeed, we have Adjusted $\mathrm{R}^{2}$ or Adjusted $\mathrm{R}$-squared $=0,846111$, so the variations of the independent variables explain $84,61 \%$ of the performance of the strategies of EU ETS players via the EUA price during phase III of the EU ETS. The objective is to show the correlations between EUA price variations and variations in other variables.

4.2. Phase III EU ETS model validation. The Fisher statistic (F-test) allows us to validate our model. By consulting $\mathrm{F}$ tabulated (theoretical or critical) with the degrees of freedom of $5 \%$ and the number of observations; we find the $\mathrm{F}$ tabulated (theoretical or critical) ${ }^{2}$ which is equal to 2,01. Then we compare this

\footnotetext{
${ }^{1}$ This statistic obeys Fisher's law with $\mathrm{p}$ and (n-p-1) degrees of freedom. The calculated value of $\mathrm{F}$ is compared to its critical value read from the Fisher's statistical table at a threshold (1- $\alpha$. A high value of $F$ indicates that the regression model is globally significant, leading to the rejection of $\mathrm{H}_{0}$; i.e. at least one of the coefficients $\beta \mathrm{i}$ is different from zero.

${ }^{2}$ To find the theoretical value on the Fisher table we need d 11 and dl2. In this respect, [dl1 $=9$ (the variables) $\left.-1=8\right]$ and [d $2=122$ (the observations) $-9=113]$.
} 
tabulated F (theoretical or critical) with our calculated F (F-statistic) which is 36.93663 , we find that F (Fstatistic) $>$ F tabulated (theoretical), we conclude that our model is validated.

The calculated value of $\mathrm{F}$ is compared to its critical value read from the Fisher table at a threshold (1- $\alpha)$. A high value of $\mathrm{F}$ indicates that the regression model is globally significant, which leads to the rejection of $\mathrm{H}_{0}$; therefore, at least one of the coefficients $\beta \mathrm{i}$ is different from zero. In accordance with the above, we validate our model because the significance of our model according to the above table confirms a value Prob(Fstatistic) $=0,000000$ which is lower than the threshold $\alpha=0,05$. At the $5 \%$ significance threshold, we can affirm that there is a significant relationship between the performance of the Carbon Finance strategy for Responsible Management and the performance of the Carbon Finance strategy for Responsible Management is influenced by the Sanitary COVID-19 crisis during phase III. Ultimately, this analysis indicates that our Research Hypothesis is therefore verified.

4.3. Analysis of Phase III EU ETS results. The objective of this analysis is to examine the significant and non-significant variables for our model. We considered the probability column « Prob.» ${ }^{3}$ column in the table above. This table of results from the EU ETS Phase III multiple regression summarizes the results of the correlation analysis. It forcefully shows the significant and non-significant variables with their correlations in this sense of the EU ETS Phase III correlation analysis results.

Table 4. Significant and non-significant variables in Phase III of the EU ETS

\begin{tabular}{|l|l|c|}
\hline \multicolumn{1}{|c|}{ Analysis variables } & \multicolumn{2}{c|}{ Correlations (hind signs) } \\
\hline \multicolumn{1}{|c|}{ Analysis variables } & $\rightarrow$ Corrélation positive & Var. 01 \\
\hline Variations in the price of Brent crude oil & $\rightarrow$ Corrélation négative & Var. 03 \\
\hline Coal Price Variations (Coal) & $\rightarrow$ Corrélation positive & Var. 08 \\
\hline $\begin{array}{l}\text { The impact of economic activity and the Sanitary COVID-19 crisis on } \\
\text { electricity production (SBF) }\end{array}$ & $\rightarrow$ Corrélation négative & Var. 10 \\
\hline Extremely Hot Dummy (DEC) & $\rightarrow$ Corrélation négative & Var. 11 \\
\hline Variations in Seasonal Standards (VNS) & \multicolumn{1}{|c|}{ Correlations (hind signs) } \\
\hline \multicolumn{1}{|c|}{ Four (04) non-significant EU ETS Phase III variables } & Var. 02 \\
\hline Changes in gas prices (Gas) & $\rightarrow$ Corrélation positive & Var. 04 \\
\hline Clean Spark Spread (CSS) & $\rightarrow$ Corrélation positive & Var. 05 \\
\hline Clean Dark Spread (CDS) & $\rightarrow$ Corrélation positive & Var. 09 \\
\hline Extremely Cold Dummy (DEF) & $\rightarrow$ Corrélation négative & \\
\hline
\end{tabular}

Source: Boutti and al. (2019).

As shown in the table above, the five significant variables in the EU ETS Phase III that are:

[Var. 01] Variations in the price of Brent (Brent): predicted sign $(+)$ and hind sign $(+)$;

[Var. 03] Variations in the price of coal (coal): predicted sign (-) and hind sign (-);

[Var. 08] The impact of economic activity and the Sanitary COVID-19 crisis on electricity production $(\mathrm{SBF})$ : predicted sign $(-)$ and hind sign $(+)$;

$>\quad[$ Var. 10] Extremely Hot Dummy (DEC): predicted sign (+) and hind sign (-);

$>\quad[$ Var. 11] Normal Seasonal Variations: predicted sign $(+)$ and hind sign (-).

The following table highlights the impact of the increase in the cost of the carbon constraint on the profits of firms listed on the EU ETS market according to the state of competition on the markets (upstream and downstream).

\footnotetext{
${ }^{3}$ This column indicates the percentage chance that the correlation between the variable and the EUA spot price is zero. In this respect, we take the variables that have the lowest probability (value less than 0.05 ).
} 
Table 5. Impact of the rising cost of carbon

\begin{tabular}{|c|c|c|}
\hline $\begin{array}{c}\text { Elasticity to changes } \\
\text { in the price of quotas }\end{array}$ & Supply of production factor & Request addressed to the company \\
\hline Inelastic & Downward trend in earnings & Trend towards sustained earnings \\
\hline Elastic & Trend towards sustained earnings & Downward trend in the deficit \\
\hline
\end{tabular}

Source: Boutti and al. (2019).

The table above highlighted the following four situations with respect to the price elasticity of quotas:

1. If the company cannot reduce the use of a production factor: downward trend in profit. Example: aluminum production if the supply of electricity is uncompetitive.

2. Customers cannot forego purchasing the company's product and the company is not experiencing an exacerbated competitive intensity: tendency to maintain profit. Example: Electricity supply in countries with monopoly and pricing freedom.

3. If the market for a production factor is highly competitive: tendency to maintain profits. Example: Aluminum production if the supply of electricity is competitive.

4. If there are substitutes with a relative advantage for their costs in carbon constraint: tendency to decrease the deficit. Example: short-haul air transport subject to competition from rail and road networks.

\section{Conclusion}

Through these econometric analyses, we observe several levels of interpretation of Carbon Finance in the test of Responsible Management. We can start with the five (05) significant variables identified, as follows:

The variable « Variations in the price of Brent (Brent) » [Var. 01], The determinants of the price of a ton of carbon are very different from those of the EU ETS test period. First, the probabilities are much lower. Indeed, one of the main determinants of the EU ETS period I had a probability of $7 \%$ with a correlation coefficient of $8 \%$. Secondly, the Variations in the price of Brent, had a probability of $0.81 \%$ with a correlation coefficient higher than that of gas, namely $19 \%$.

The variable « Variations in the price of coal (Coal)» [Var. 03], is a significant variable with a negative backward sign. Coal was used more than natural gas in power plants during the Sanitary COVID-19 crisis. The statistical test applied allows us to pay particular attention to the negative (-) hind sign. In this respect, the use of coal, compared to other energies and particularly gas, for energy production, increases $\mathrm{CO} 2$ emissions. In the same vein, carbon market companies were facing a crisis situation (Sanitary COVID-19 crisis). In this respect, in order to obtain liquidity, sales of allowances contributed to an increase in activity in the carbon market during this crisis period (Chevallier, 2012).

The variable « The impact of economic activity and the Sanitary COVID-19 crisis on electricity production $(\mathrm{SBF}) »[$ Var. 08] is significant in our model. In this respect, this variable has a positive sign $(+)$ after the fact, as does the variable « Variations in the price of Brent (Brent) » [Var. 01]. We can argue that the variable [Var. 08] has a positive influence on EUA prices. We can conclude that industrial actors were motivated to reduce the use of natural gas on behalf of coal (in the short term to face the Sanitary COVID-19 crisis and as part of a long-term Responsible Management strategy, at the end of the period).

The «Extremely Hot Dummy (DEC) » [Var. 10], is a significant variable. That said, when temperatures are extremely high, we are faced with a situation of increasing energy requirements for air conditioning, which increases $\mathrm{CO} 2$ emissions.

$>\quad$ The variable « Variations in Seasonal Standards (VNS)» [Var. 11], is a significant variable. This said, when temperatures are extremely low, we are faced with a situation of increasing heating energy needs. According to the above, energy consumption increases and, in turn, increases $\mathrm{CO} 2$ emissions. On the other hand, when the temperature is very hot in summer, we are faced with a situation of increasing energy needs for air conditioning. In these circumstances, EUA prices have been increased on the market. This analysis is very relevant with that of Chevallier (2012). A colder than usual temperature in winter increases energy generation and, in particular, the need for heating fuel. A very hot temperature in summer increases energy consumption for air conditioning. In the case of cold winters and hot summers, emissions are, all other things being equal, higher, which leads to an increase in the price of allowances on the market. 
To conclude this point, we have identified five (5) types of determinants of the EUA price for the third phase of the EU ETS: the first determinant «Variations in the price of Brent crude oil » [Var. 01], the second determinant « Coal Price Variations (Coal)» [Var. 03], the third determinant « The impact of economic activity and the Sanitary COVID-19 crisis on power generation (SBF) » [Var. 08], the fourth determinant « Extremely Hot Dummy (DEC) » [Var. 10], and finally « Variations in Seasonal Standards (VNS) » [Var. 11].

In this respect, we tried to show using multiple regression that carbon price variations react to economic activity and the Sanitary COVID-19 crisis during period III of the EU ETS. According to Chevallier (2012) financial analysis, the EUA market had six (6) fundamental disconnections during period III of the EU ETS, as follows:

$>\quad$ 1st fundamental disconnection in 2008: Subprime Financial Crisis;

$>\quad$ 2nd fundamental disconnection in 2009: New equilibrium in the soft recovery;

$>\quad$ 3rd fundamental disconnect in 2010: Fukushima incident;

$>\quad$ 4th fundamental disconnection in 2010: Debt crisis and further deterioration of growth prospects;

$>\quad$ 5th fundamental disconnection in 2011: Energy Efficiency (EE) discussions.

$>\quad$ 6th fundamental disconnection in 2019: Sanitary COVID-19 crisis and further deterioration of growth prospects.

We can conclude that our results are in perfect symbiosis with the literature reviews. The interest for the company is to understand the ins and outs of Carbon Finance and to make the best use of the allocated quotas in order to optimize their financial and economic performance. Ultimately, carbon finance will help us find a way to meet the climate change challenge only when all elements of the economy-consumers, producers, and regulators - have to factor GHGs into their bottom line.

\section{Implications for future}

More than sixty years after the economic work of Ronald Coase (1960) on negative externalities, the European carbon market has grown significantly and has become the main market for environmental instruments in the world. In the introduction to this article, we raised the recent development of carbon finance and its relevance in the fight against climate change.

Carbon Finance covers the different market mechanisms included in the Kyoto Protocol and encompasses all the activities that contribute to making GHGs a tradable good. Market mechanisms have created a carbon price signal, which companies must integrate into their strategies in order to optimize their GHG emission reductions.

During our reading, we were able to highlight key concepts and theories relating to carbon finance which led us to consider two main themes: determining the price of carbon and the impact of its accounting treatment on the assets of the Business and its financial profitability. These themes are closely linked to each other, insofar as the carbon price is subject to several influencing factors (regulatory decisions, primary energy prices, macroeconomic factors, etc.) and itself has a direct impact on the valuation of the market.

To carry out our study, we decided to treat each topic in a different way depending on their specificities and the academic work already done. We studied the determinants of the price per tonne of carbon using a quantitative methodology. We performed an econometric study based on a linear regression model in order to test our research hypothesis.

This information is essential for companies to integrate carbon risk into their long-term strategies and adapt their sales and purchasing strategies to the carbon market. These studies have enabled us - quite modestly - to enrich the existing literature and make managerial recommendations, mainly based on the need for legal, financial and informational monitoring of the carbon market. Clear identification of carbon risks is essential. We have thus highlighted some of the challenges and opportunities of Carbon Finance, the subject being very broad to deal with. We would like to conclude this part of the implications for the future of our article on the need for better supervision of the carbon market. In order to bring out a robust long-term price signal in Europe and on all current and future carbon markets.

In terms of courses, this article may be appealing to courses in finance, such as principales of financial markets, financial economics and financial econometrics. It wil also be relevant to courses in energy, environmental 
and resource economics as it covers the EU ETS and the Kyoto Protocol which constitutes a new commodity, it will also be eligible to courses on commodity markets and risk management on these markets. Finally, the measure of risk in climate change in $\mathrm{CO} 2$ spot and a future is detailed based on commodity markets models and linear regressions. Besides, carbon price risk management strategies are described by the means of an econometric analysis of the factors influencing fuel-switching in the power sector.

Author Contributions : conceptualization, El Amri, A., Boutti, R.; methodology, El Amri, A., Boutti, R., Sahib Eddine, A.; validation, El Amri, A., Boutti, R.; formal analysis, El Amri, A., Boutti, R., Oulfarsi, S., Sahib Eddine, A.; investigation, El Amri, A., Boutti, R., Hmioui, A.; resources, El Amri, A., Boutti, R., Hmioui, A.; data curation, El Amri, A., Sahib Eddine, A.; writing - original draft preparation, El Amri, A., Oulfarsi, S., Boutti, R.; writing - review and editing, El Amri, A., Boutti, R., Sahib Eddine, A.; visualization, El Amri, A., Oulfarsi, S.; supervision, Boutti, R., Sahib Eddine, A.; project administration, Boutti, R., Sahib Eddine, A.; funding acquisition, Boutti, R., Sahib Eddine, A., Oulfarsi, S.

\section{References}

1. Alberola, E., Chevallier, J. (2009). European carbon prices and banking restrictions: evidence from Phase I (2005-2007). The Energy Journal, 30(3), 51-79. Retrieved from: https://ideas.repec.org/a/aen/journl/2009v30-03-a03.html

2. Alberola, E., Chevallier, J., Cheze B. (2009). Emissions compliances and carbon prices under the EU ETS: a country specific analysis of industrial sectors. Journal of Policy Modelling, 31, 446-462. Retrieved from: https://ideas.repec.org/a/eee/jpolmo/v31y2009i3p446-462.html

3. Alberola, E., Chevallier, J., Cheze B. (2008). Price drivers and structural breaks in European carbon prices 2005-2007. Energy policy, 32(2), 787-797. Retrieved from: https://econpapers.repec.org/article/eeeenepol/v_3a36_3ay_3a2008_3ai_3a2_3ap_3a787-797.htm

4. Alcott, B. (2008). The sufficiency strategy: Would rich-world frugality lower environmental impact? Ecological Economics, 770-786. Retrieved from: https://doi.org/10.1016/j.ecolecon.2007.04.015

5. Anderson, J. C. et Gerbing, D. W. (1988). Structural equation modelling in practice: A review and recommended two-stepapproach, Psychologicalbulletin, 103(3), 411-423. Retrieved from: https://pdfs.semanticscholar.org/2265/a198e55665ed3df0f19688350567dab593de.pdf?_ga=2.21391144 7.1042702225.1590342168-1378669878.1588811588

6. Andreas Karaoulanis, A., Vasiliki, K. (2018). Tourism in Developing Countries. The Path Towards Sustainable Development and Its Interaction with The Local Communities, The Environment and The Hu-man Factor. SocioEconomic Challenges, 4(2), 80-86. Retrieved from: https://doi.org/10.21272/sec.4(2).80-86.2018

7. Ariely D. (2009). The End of Rational Economics, Harvard Business Review. July-August 2009 Issue. Retrieved from: https://hbr.org/2009/07/the-end-of-rational-economics

8. Aven T. (2015). Implications of black swans to the foundations and practice of risk assessment and management, Reliability Engineering \& System Safety, 134, 83-91. Retrieved from: https://doi.org/10.1016/j.ress.2014.10.004

9. Baron, R., Aasrud, A., Sinton, J., Campbell, N., Jiang, K. \& Zhuang, X. (2012). Policy options for low carbon power generation in china. International Energy Agency, Energy Research Institute, Insights Series, 74. Retrieved from: http://www.iea.org/publications/insights/insightpublications/Insight PolicyOptions_Low Carbon_China.pdf

10. Bhandari, M.P. (2019). Sustainable Development: Is This Paradigm the Remedy of All Challenges? Does Its Goals Capture the Essence of Real Development and Sustainability? With Reference to Discourses, Creativeness, Boundaries and Institutional Architecture. SocioEconomic Challenges, 3(4), 97-128. Retrieved from : https://doi.org/10.21272/sec.3(4).97-128.2019

11. Bhowmik, D. (2019). Decoupling CO2 Emissions in Nordic countries: Panel Data Analysis. SocioEconomic Challenges, 3(2), 15-30. Retrieved from: https://doi.org/10.21272/sec.3(2).15-30.2019 
Financial Markets, Institutions and Risks, Volume 5, Issue 1, 2021 ISSN (online) - 2521-1242 ISSN (print) - 2521-1250

12. Bhowmik, D. (2018). Financial Crises and Nexus Between Economic Growth and Foreign Direct Investment. Financial Markets, Institutions and Risks, 2(1), 58-74. http://doi.org/10.21272/fmir.2(1).5874.2018

13. BONN. (2002). A guide to the climate change convention process. UNFCCC working paper, 49. Retrieved from: https://unfccc.int/resource/process/guideprocess-p.pdf

14. Boutti, R., El Amri, A., Rodhain, F. (2019). Multivariate Analysis of a Time Series EU ETS: Methods and Applications in Carbon Finance. Financial Markets, Institutions and Risks, 3(1), 18-29. Retrieved from: http://doi.org/10.21272/fmir.3(1).18-29.2019.

15. Bożena, S., Vynnychenko, N. (2018). Evaluating of the financial equalization system in Ukraine.Financial Markets, Institutions and Risks, 2(1), 25-36. Retrieved from: http://doi.org/10.21272/fmir.2(1).25-36.2018

16. Broome, J. (1992). Counting the costs of global warming. White House Press. Retrieved from: https://philpapers.org/archive/BROCTC-12.pdf

17. Bunn, D., Fezzi, C. (2007). Interaction of European carbon trading and energy prices. Fondazione Eni Enrico Mattei working paper, No. 123, 25 p. Retrieved from: https://www.feem.it/en/publications/feemworking-papers-note-di-lavoro-series/interaction-of-european-carbon-trading-and-energy-prices/

18. Carbon Disclosure Project (CDP). (2010). Supply Chain Report. Retrieved from: www.cdproject.net/CDPResults/CDP-Supply-Chain-Report_2010.pdf

19. CCNUCC. (2007). Investment and Financial Flows to Address Climate Change. Secretariat of the United Nations Framework Convention on Climate Change, Bonn, 272 p. Retrieved from: https://unfccc.int/resource/docs/publications/financial flows.pdf

20. Chevallier, J. (2012). Econometric Analysis of Carbon Markets: the European Union Emissions Trading Scheme and the Clean Development Mechanism. Springer. Retrieved from: https://www.springer.com/gp/book/ 9789400724112

21. Chin, W. W. (1998). The partial least squares approach to structural equation modeling. Modern methods for business research, 295(2), 295-336. Retrieved from: https://psycnet.apa.org/record/1998-07269-010

22. Christensen, T. H., Godskesen, M. I., Gram-Hanssen, K., Quitzau, M-B., \& Røpke, I. (2007). Greening the Danes? Experience with consumption and environment policies. Journal of Consumer Policy, 30(2), 91-116. Retrieved from: https://doi.org/10.1007/s10603-007-9029-2

23. Christiansen, A. C., Arvanitakis, A., Tangen, K. \& Hasselknippe, H. (2005). Price determinants in the EU emissions trading scheme, Climate Policy, 5:1, 15-30, Retrieved from: DOI: 10.1080/ 146930 62.2005 .9685538

24. Coase, R. H. (1960). The problem of social cost, Journal of Law and Economics, Vol. 3, 1-44. The University of Chicago Press. Retrieved from: http://www2.econ.iastate.edu/classes/tsc220/hallam/Coase.pdf

25. Cosgrove-Sacks, C., Dembinski, P. H. (2009). Ehics In Finance: Surviving the Crisis. Finance \& Bien Commun, 1(33), 5-15. Retrieved from: https://www.cairn.info/revue-finance-et-bien-commun-2009-1-page5.htm

26. De Bandta, O., Bruneaub, C., El Amri, W. (2008). Stress testing and corporate finance. Journal of Financial Stability, 4(3), 258-274. Retrieved from: https://doi.org/10.1016/j.jfs.2008.03.001

27. Dovhan, Z., Kravchuk, I., Karaś, P. (2017). The financial instruments market - an institutional approach. Financial Markets, Institutions and Risks, 1(1), 22-28. http://doi.org/10.21272/fmir.1(1).22-28.2017

28. El Amri, A., Boutti, R., Oulfarsi, S., Rodhain, F., Bouzahir, B. (2020). Carbon finan-cial marets underlying climate risk management, pricing and forecasting: Fundamental analysis. Financial Markets, Institutions and Risks, 4(4), 31-44. Retrieved from: https://doi.org/10.21272/fmir.4(4).31-44.2020

29. El Amri, A., Boutti, R., Rodhain, F. (2020). Sustainable Finance at the time of Institu-tions: Performativity through the lens of Responsible Management in Morocco. Financial Markets, Institutions and Risks, 4 (2), 5264. Retrieved from: https://doi.org/10.21272/fmir.4(2).52-64.2020

30. Gadzo S. G., Anaman, Em. At., Pobbi, M., Asiamah, S. K. (2019). Industry Concentration and Asset Quality as Determinate of Financial Performance: A Comparative Study of Indigenous and Foreign Owned 
Universal Banks. Financial Markets, Institutions and Risks, 3(2), 79-90. http://doi.org/10.21272/fmir.3(2).79$\underline{90.2019}$

31._Heinemann, S. (2011). Financial Derivatives and Responsibility - How To Deal Ethically With Financial Risk. Finance \& Bien Commun, 1(39), 45-56. Retrieved from: https://www.cairn.info/revue-finance-et-bien-commun2011-1-page- 45.htm

32. IEA Ministerial Statement on Energy and Climate Change. (2015). Energy Matters : How COP 21 can shift the energy sector onto a low-carbon path that supports economic growth and energy access, International Energy Agency, 8 p. Retrieved from : http://www.iea.org/media/presentations/Energy Matters bro chure.PDF

33. International Renewable Energy Agency, IRENA. (2014). IRENA communiqué on the Africa clean energy corridor. Africa clean energy corridor ministerial, Abu Dhabi, United Arab Emirats. Retrieved from: http://www.irena.org/DocumentDownloads/events/IRENA_ACEC_Communique_2014.pdf

34. IPCC. (2014). Climate Change 2014 : Impacts, Adaptation, and Vulnerability Summary for Policymakers, Cambridge University Press, Cambridge, United Kingdom and New York, NY, USA, 44. Retrieved from: https://ipcc-wg2.gov/AR5/images/uploads/IPCC_WG2AR5_SPM_Approved.pdf

35.Jaffe, A.B., R.G. Newell, \& R.N. Stavins (2004). Economics of energy efficiency. 79-90 in Cleveland, C.J. (ed), Encyclopedia of Energy, Volume 2, San Diego and Oxford (UK): Elsevier. Retrieved from: https://scholar.harvard.edu/files/stavins/files/encyclopedia_of_energy_2004.pdf

36. Kostel, M., Leus, D., Cebotarenco, A., Mokrushina, A. (2017). The Sustainable Development Goals for Eastern Partnership Countries: Impact of Institutions. Socio-Economic Challenges, 1(3), 79-90. http://doi.org/10.21272/sec.1(3).79-90.2017

37. Lebatt, S. et White, R., R., (2007). Carbon finance: the financial implications of climate change. John Wiley \& Sons, Inc. Retrieved from: https://www.wiley.com/en-us/Carbon+Finance\%3A+The+Financial + Implications + of + Climate + Change-p-9780471794677

38. Lieonov, S., Didenko, I. (2017). Assessment of demand, supply and equilibrium price on the deposit market of Ukraine, Financial Markets, Institutions and Risks, 1(1), 5-13. Retrieved from: https://armgpublishing.sumdu.edu.ua/wp-content/uploads/2016/12/files/fmir/issue1/FMIR 1 2017_Lieonov 5-13.pdf

39. Nordhaus, W. D. (1991). To slow or not to slow: the economics of the greenhouse effect. Economic Journal, 101, 920- 937. Retrieved from: https://www.jstor.org/stable/2233864?seq=1

40. OCDE. (2010). Climate Policy and Technological Innovation and Transfer: an overview of trends and recent empirical analysis: empirical results. Retrieved from: www.oecd.org/dataoecd/54/52/45648463.pdf

41. Popoola, M. Ak., Brimah, Am. N., Gbadeyan, A. R. (2019). Financial Institutions Micro Loans: A Strategy for Reducing Poverty in Nigeria. Financial Markets, Institutions and Risks, 3(3), 13-18. http://doi.org/10.21272/fmir.3(3).13-17.2019

42. Priem R. L., Rasheed A. M.A., Kotulic A. G. (1995). Rationality in Strategic Decision Processes, Environmental Dynamism and Firm Performance, Journal of Management. Retrieved from: http://journals.sagepub.com/doi/abs/10.1177/014920639502100506

43. Rubanov, P., Marcantonio, A. (2017). Alternative Finance Business-Models: Online Platforms. Financial Markets, Institutions and Risks, 1(3), 92-98. Retrieved from: http://armgpublishing.sumdu.edu.ua/ journals/fmir/issue-3/article-9/

44. Rydge, J. (2015). Implementing Effective Carbon Pricing: contributing paper for seizing the global opportnity partnerships for better growth and a better climate, New Climate Economy, London and Washington, DC. Retrieved from: http://www.newclimateeconomy.report/misc/working-papers/

45. Sifah, D. (2009). Ethics: An Essential Prerequisite Of The Financial System. Finance \& Bien Commun, 1(33), 46-57. Retrieved from: https://www.cairn.info/revue-finance-et-bien-commun-2009-1-page-46.htm

46. Singh, S.N. (2018). Regional Disparity and Sustainable Development in North-Eastern States of India: A Policy Perspective. Socio-Economic Challenges, 2(2), 41-48. http://doi.org/10.21272/sec.2(2).41- 48.2018 
47. Soleimani Zoghi, F. (2017). Risk Management Practices and SMEs: An empirical study on Turkish SMEs. International Journal of Trade, Economics and Finance, Vol. 8, No. 2, 123-127. Retrieved from: http://10.18178/ijtef.2017.8.2.550

48. Springer, U. (2003). The market for tradable GHG permits under the Kyoto Protocol: a survey of model studies. Energy Economics, 25, 527-551. Retrieved from: https://econpapers.repec.org/ article/eeeeneeco/v 3a25 3ay 3a2003 3ai 3a5 3ap 3a527-551.htm

49. Starchenko, L. (2020). Impact of Gender Aspects of Sustainable Entrepreneurship on Country Innovative Development. Marketing and Management of Innovations, 4, 304-311. Retrieved from: http://doi.org/10.21272/mmi.2020.4-25

50. Taliento, M., Netti, A. (2020). Corporate Social/Environmental Responsibility and Value Creation: Reflections on a Modern Business Management Paradigm. Business Eth-ics and Leadership, 4(4), 123-131. Retrieved from: http://doi.org/10.21272/bel.4(4).123-131.2020

51. Ted Prince E. (2018). Risk Management and Behavioral Finance. Financial Markets, Institutions and Risks, 2(2), 5-21. Retrieved from: https://armgpublishing.sumdu.edu.ua/journals/fmir/volume-2-issue2/article-1/

52. Toth, F. L. (1995). Discounting in integrated assessments of climate change. Energy Policy, Elsevier, vol. 23(4-5), pp. 403-409. Retrieved from: https://ideas.repec.org/a/eee/enepol/v23y1995i4-5p403-409.html

53.UNEP FI. (2013). Portfolio carbon : measuring, disclosing and managing the carbon intensity of investments and investment portfolios. UNEP FI Climate Change Advisory and Investment Commission. $40 \mathrm{p}$. Retrieved from: http://www.unepfi.org/fileadmin/documents/UNEP FI Investor Briefing Portfolio Carbon.pdf

54.Vargas-Hernández, J. G., Orozco-Quijano, E. P., Virchez, J. (2018). Critical Analysis On Institutional Capital On Trade And Environmentally Sustainable Development Under NAFTA. SocioEconomic Challenges, 4(2), 21-31. Retrieved from: https://doi.org/10.21272/sec.4(2).21-31.2018

55. Vasilyeva, T., Lyeonov, S., Lopa, L. (2018). Forecasting Supply and Demand In the Regional Labor Market: In Search of Optimal Proportions of Financing Vocational Education Institutions In the Region. SocioEconomic Challenges, 2(1), 69-84. Retrieved from: https://doi.org/10.21272/sec.2(1).69-84.2018

56. Vidar Gudmundsson, S. and Lechner, C. (2013). Cognitive Biases, Organization, and Entrepreneurial Firm Survival, European Management Journal, 31(3):278-294, DOI: 10.2139/ssrn.2186062. Retrieved from: https://www.researchgate.net/publication/255725144 Cognitive Biases Organization and Entrepreneurial Firm Survival

57. Wolrd Bank Group (2010). The economics of adaptation to climate change, The World Bank, Washington, D.C., 84. Retrieved from: http://siteresources.worldbank.org/EXTCC/Resources/ EACC_Final SynthesisReport0803_2010.pdf 